\title{
Two new Subspecies of the Liolaemus fitzingeri Complex from Argentina
}

\author{
José M. Cei and José A. Scolaro \\ Instituto Biologia Animal, Universidad Nacional de Cuyo, Mendoza, Argentina and Instituto Nacional Patagónico, \\ Puerto Madryn, Chubut, Argentina.
}

ABSTRACT-Liolaemus fitzingeri cuyanus $n$. subsp. from sandy regions north of the Rio Colorado (Argentina) and $L$. fitzingeri xanthoviridis $n$. subsp. from coastal range of Chubut (Argentina) are described. The former is easily distinguishable from other known forms of the group by a lower number of dorsal scales, lack of ventral melanism and the presence of a distinct black antehumeral band. $L$. fitzingeri xanthoviridis is distinguishable from its nearest relative $L$. fitzingeri canqueli by shorter limbs, more distinctly keeled dorsal scales, anterior margin of ear with smaller non-proyecting scales, and different color pattern.

Psammophilous lizards of the $L$. fitzingeri complex are widespread Argentine iguanids, living in arid and semiarid regions, south of $28^{\circ} \mathrm{S}$. The nomenclatural history of the species has been noted previously (Cei, 1973, 1975) but no attempt has yet been made to fix definitively the identity of the syntypes of Proctotretus fitzingeri Dumeril and Bibron (1841), whose locality "Chile" is obviously erroneous. These syntypes shall be discussed elsewhere, but we have determined conclusively that they do not belong to either of the subspecies here described. Although Koslowsky (1895) cited the species for Catamarca, all subsequent authors regarded it as a characteristic Patagonian lizard and emphasized its remarkable population variation. Eulaemus affinis Girard 1858 and Liolaemus melanops Burmeister 1888 have been considered to be synonyms of Liolaemus fitzingeri (Boulenger 1885; Peters and Donoso Barros 1970), although the name melanops was later applied to an isolated population from Meseta Canquel, Chubut, south of Chubut River [L. fitzingeri melanops (Cei, 1973)]. The name was later properly applied to the populations north of Chubut River, found in xerophilous environments from Somuncurá plateau (Rio Negro) to Valdes peninsula (Cei, 1975; Cei and Scolaro, 1977a; Scolaro and Cei, 1977) and the population formerly called Liolaemus fitzingeri melanops from meseta Canquel was described as a new geographical form ( $L$. fitzingeri canqueli $\mathrm{Cei} 1975$ ). The nominate form $L$. fitzingeri fitzingeri was there referred to the southernmost Patagonian populations, in accordance with Donoso Barros's redescription (1966:293: "terra typica, Chile Chico, Prov. Aysen" (sic)) and Peters and Donoso Barros's Catalogue of the Neotropical Squamata (1970).

Further morphological and immunological studies carried out on polymorphic populations from Valdes Peninsula and Puerto Madryn, Chubut, allowed us to place the lizard described as Liolaemus goetschi by Muller and Hellmich (1938) in the synonmy of Liolaemus fitzingeri melanops. It was based upon northern Patagonian populations from Rio Negro, close to the Rio Colorado (Cei and Scolaro, 1977a). More recently field research by the senior author in San Juan and La Rioja province (western central Argentina) has revealed a new distinct northern population of the fitzingeri group. Another different population was discovered by the second author south of Chubut River, along the Atlantic coast. Both of these taxa are described herein and their relation to other geographical races of Liolaemus fitzingeri is examined with reference to ecological characteristics.

Specimens cited are in the Museo Zoologico, Florence, Italy (MF), and in the Instituto Biologia Animal, Universidad Nacional de Cuyo, Mendoza, Argentina (IBA-UNC).

-Present Address: Rancho Somuncurá, Rua F. de Figueiredo, Birre, 2750 Cascais, Portugal. 

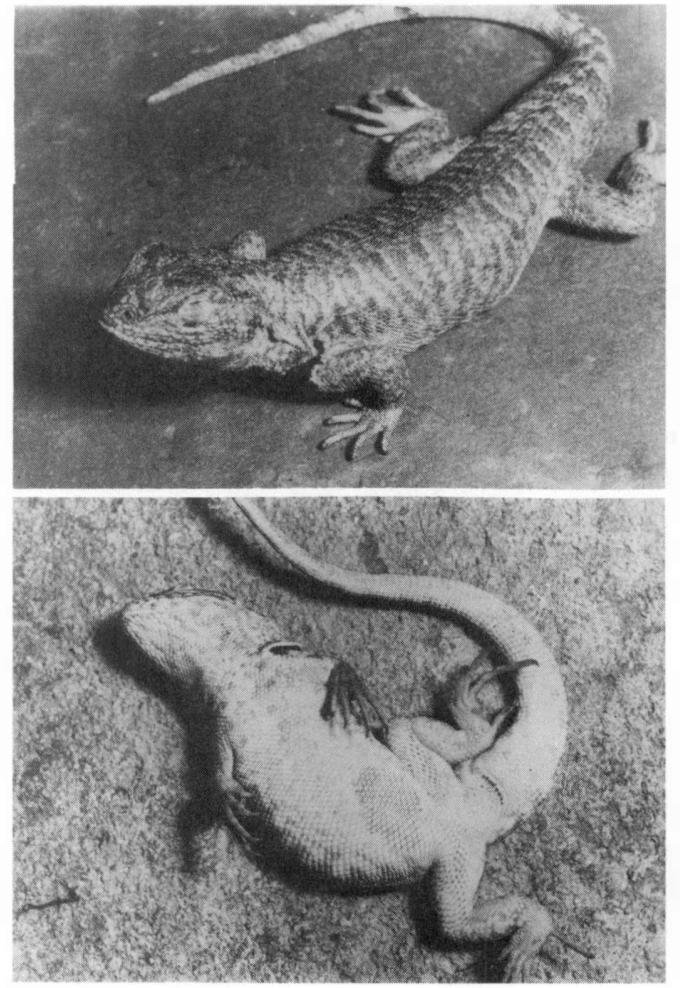

FIGURE 1. Liolaemus fitzingeri cuyanus male, from sandy dunes of Caucete, San Juan province, western Argentina.
Liolaemus fitzingeri cuyanus subsp. nov.

(Fig. 1)

Holotype. MF 22830, male, $10 \mathrm{~km} \mathrm{E}$ Caucete, $400 \mathrm{~m}$, San Juan Province, Argentina, J. M. Cei, 19 Nov. 1977.

Paratypes.MF 22831-22834, same data as holotype; MF 22851-22852, near Caucete, San Juan Prov., J. M. Cei, 5 Apr. 1978; MF 23808, 6 km E Caucete, San Juan Prov., J. M. Cei, 24 Oct. 1978; MF 22829, near Encon, San Juan Prov. J. M. Cei,, 19 Nov. 1977; MF 22850, same locality, J. M. Cei,, 10 Febr. 1978; MF 23814, Rio Bermejo, San Juan Prov., 12 Nov. 1978; IBA-UNC 1929. 1-5, dunes of Baldecitos, Talampaya flats, $1400 \mathrm{~m}$, La Rioja Prov., J. M. Cei, and L. P. Castro, 15 Nov. 1976; MF 23809 23811, 40 km E Chepes, La Rioja Prov., J. M. Cei,, 12 Nov. 1978; MF 23812, 10 km SE Mascasin, La Rioja Prov., J. M. Cei, 12 Nov. 1978; MF 23815-23820, 3 km SW Mascasin, La Rioja Prov., J. M. Cei, 18 Nov. 1978; MF 23813, 12 km E Aimogasta, La Rioja Prov., J. M. Cei, 16 Nov. 1978; IBA-UNC 1269, Alpero, Lavalle flats, Mendoza Prov., J. M. Cei and L. P. Castro, 23 Sept. 1977; IBA-UNC 73, 30 km S Desaguadero bridge, Mendoza Prov., F. Roig, 10 Dec. 1955; IBA-UNC 1245.1-2, Algodones, Guanacache swamps, Mendoza Prov., J. M. Cei and L. P. Castro, 5 Oct. 1976; MF 22835-

22848, Carrizal del Medio, Mendoza Prov., J. M. Cei and A. Lattuada, 26 Nov. 1977; MF 23800-23807, Carrizal del Medio, Mendoza Prov., J. M. Cei, 26 Febr. 1978; MF 22853-22854, Carrizal del Medio, Mendoza Prov., J. M. Cei, 27 Apr. 1978; IBA-UNC 1271,1-15, Carrizal del Medio, Mendoza Prov., J. M. Cei and L. P. Castro, 7 Dec. 1977; IBA-UNC 1206.1-16, Carrizal del Medio, Mendoza Prov., L. P. Castro, 10 March 1976; IBA-UNC 1322.1-9, Carrizal del Medio, Mendoza Prov., J. M. Cei, 12 March 1978. A total of 102 specimens have been examined.

Diagnosis. A large Liolaemus differing from other forms of the fitzingeri group in having larger dorsal and ventral scales, no ventral melanism, and a distinct black antehumeral band, darker in males.

Description of holotype. Body elongate, slender, with large hind leg, reaching the shoulder. Rostral twice as wide as high. Nasals enlarged, above and anterior to canthal ridge, separated from rostral and supralabials by a row of small rectangular scales. Nasal opening directed anterolaterally. Internasals, frontonasals and prefrontals enlarged, polygonal, smooth and symmetrically arranged. Supraorbital semicircles very distinct, medially separated by two rows of rectangular, regular scales, partially fused. Seven regular large and transversely widened supraoculars, medially contacting supraorbital semicircles, laterally separated from superciliaries by 2-3 rows of smaller, irregular scales. Interparietal slightly smaller than parietals, separated from supraorbital semicircles by one row of larger scales, regularly arranged. Central "eye" of interparietal very distinct. Scales of parietal and upper temporal region smaller than parietals, smooth and regularly arranged. An elongate, sharp canthal, followed by five, elongate overlapping superciliaries; the canthal and superciliaries together forming a moderate crest. Orbit bordered below by a very large subocular, separated from supralabials by a single row of enlarged scales. Three-four loreolabials. Temporals moderate, rhomboidal and imbricate, smooth or slightly keeled; those bordering anterior margin of ear smaller, conical and prominent. Nine enlarged, smooth supralabials. Mental almost rounded. 
Eight infralabials, similar to supralabials. Six enlarged postmental and lateral gulars. Gulars small, smooth and imbricate, becoming bristly in the posterior gular region.

Sides of the neck almost granular, with evident antehumeral and longitudinal folds. Smaller granular black scales on the antehumeral band. Dorsal nuchals somewhat smaller, imbricate and distinctly keeled. Dorsal body scales distinctly keeled, arranged in regular longitudinal rows. Dorsolaterals weakly keeled, becoming granular on the axilla and groin and grading into smooth, rhomboidal and regularly imbricate ventral scales, slightly larger than dorsals. Proximal caudal scales anterior to the first autotomy segment similar to the dorsal scales, above and below. Distal caudal scales squarish, diagonally keeled above and below. Upper limb scales distinctly keeled, imbricate. Ventral limb scales smooth imbricate, granular near axilla and groin. Thigh granular posteriorly, with an evident patch of enlarged spinose scales on posterior border. Supracarpals, supratarsals and supradigitals smooth. Infradigital lamellae tricarinate. Scales at midbody $63 ; 17$ scales contained in head length; 29 lamellae under the fourth toe; 12 preanal pores.

Snout-vent length $88 \mathrm{~mm}$; tail $112 \mathrm{~mm}$; foreleg $31 \mathrm{~mm}$; hind leg $48 \mathrm{~mm}$; distance from axilla to groin $42 \mathrm{~mm}$.

Dorsal background white-yellowish, crossed by eleven brownish transverse bands, whitebordered posteriorly and widened on the vertebral line. The pattern follows on the tail as regular median dark blotches, bordered with white posteriorly. Limbs banded or spotted with brown. Head uniformly pale brownish. Gular region and flanks faintly marked with brown. Ventrally whitish, immaculate. A transverse faint dark band on throat. A distinct velvet-black antehumeral band from throat to shoulder.

Variation. A sample of 20 adult males and 23 adult females has been studied for gonadal structure and maturity. The minimum, average and maximum snout-vent lengths is $\mathrm{mm}$ are: 63.0 $(79.0 \pm 1.8) 94.0$ in males, $62.0(72.8 \pm 1.7) 90.0$ in females. No significant sex differences in size are found.

The range of variation of midbody scales is $63-70$. Color patterns in both sexes are slightly variable: the black antehumeral collar is faint or very faint in females but a yellow wash is often present on sides of neck and throat in both sexes. Usually the females are very similar to males. Preanal pores $(7-12)$ are not found in female specimens, however are present in young males having still unripe testicles.

Range. Liolaemus fitzingeri cuyanus is a specialized psammophilous lizard known only from dunes or sandy soils in La Rioja, San Juan and Mendoza provinces. In La Rioja Province it occurs from Catamarca to San Juan; records of this form are from Chepes, Aimogasta and Talampaya sandy flats. In San Juan Province it occurs widely in the dry Rio Bermejo basin; and in Mendoza Province from the Guanacache and Desaguadero subdesertic flats as far south as the Rio Tunuyan basin. It is probably scattered southward to Rio Colorado through southern Mendoza and La Pampa Province.

Etymology. The subspecific name cuyanus refers to the "Cuyo" region, ancient denomination of San Juan and Mendoza provinces.

\section{L. fitzingeri xanthoviridis subsp. nov.} (Fig. 2)

Holotype. MF 22810, adult male, $18 \mathrm{~km}$ NW Dos Pozos, Chubut, J. A. Scolaro, 18 Oct. 1977.

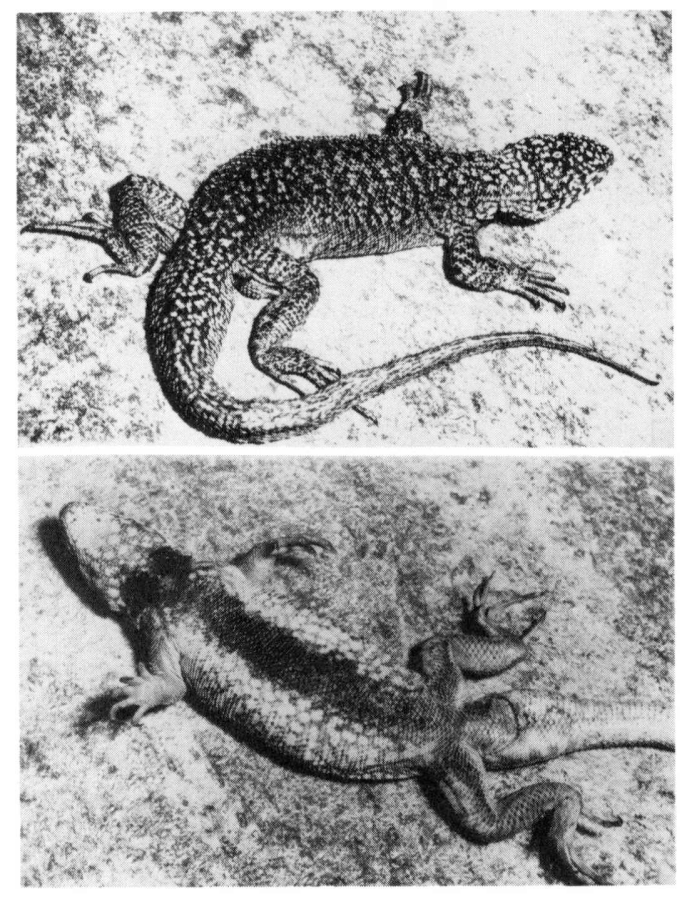

FIGURE 2. Liolaemus fitzingeri xanthoviridis male, from Dos Pozos, Atlantic coast of Chubut, Patagonia. 
Paratypes. MF 22809, 22811, 22812, same data as holotype; FM 22805-22808, Estancia Santa Clara, 25 km NW Dos Pozos, Chubut, J. A. Scolaro, 20 March 1978; IBA-UNC 1080.1-4, 1081, 1082, $7 \mathrm{~km}$ from Trelew, S Rio Chubut, J. A. Scolaro, 20 Dec. 1975; MF 22813-22814, 5-7 km S Rio Chubut, J. A. Scolaro, 20 Nov. 1977; MF 22815-22819, 30 km NW Dos Pozos, Chubut, J. A. Scolaro, 22 Dec. 1977. A total of 21 specimens has been obtained.

Diagnosis. A large slender Liolaemus differing from its nearest relative $L$. fitzingeri canqueli in having shorter hind limbs; small, non-proyecting scales bordering anterior margin of ear; distinctly keeled dorsal scales; ventrals never larger than dorsals and different color pattern. It differs from $L$. fitzingeri fitzingeri by its very different color pattern, the different scutellation of anterior margin of ear and the extensive dark coloration on throat and chest. It differs from L. fitzingeri melanops by the larger size of males, higher number of scales at midbody and different color pattern. It is obviously distinguishable from $L$. fitzingeri cuyanus by larger hind limbs, smaller dorsal scales and very different dorsal and ventral coloration.

Description of holotype. Body slender, the hind limb reaching axilla. Rostral twice as wide as high. Nasal enlarged, subtriangular, above and anterior to canthal ridge, separated from rostral and supralabials by a row of moderate rectangular scales. Nasal opening directed anterolaterally. Internasals, frontonasals and prefrontals enlarged, almost symmetrically arranged. Supraorbital semicircles, distinct, medially separated by two rows of prominent round scales. Eight large, transversely widened supraoculars, medially contacting supraorbital semicircles, laterally separated from superciliaries by two irregular rows of smaller polygonal scales. Interparietal slightly wider than parietals, separated from supraorbital semicircles by one or two series of large scales, irregularly arranged. Central "eye" of interparietal very distinct. Scales of parietal and upper temporal region slightly smaller than parietals, smooth, very irregularly arranged. A strongly convex canthal, followed by 5-6 elongate, overlapping superciliaries; the canthal and superciliaries together forming a moderately proyecting crest. Enlarged smooth subocular separated from supralabials by a single row of enlarged rectangular or subtriangular scales. Few, moderate loreolabials. Temporals rhomboidal, smooth, imbricate; those bordering anterior margin of ear smaller, not proyecting. Eight enlarged rectangular supralabials. Mental subtriangular. Eight smaller, enlarged infralabials. Sixseven transversally widened postmental and lateral gulars. Gulars rounded, smooth, imbricate, becoming smaller in the posterior region.

Sides of neck mostly granular; strong antehumeral and longitudinal folds. Dorsal nuchals granular, becoming larger and distinctly imbricate on shoulder. Dorsal body scales heterogeneous, keeled, imbricate, smaller along vertebral line. Dorsolaterals unkeeled, imbricate, becoming gradually smaller and granular on axilla and groin. Ventrals smooth, rhomboidal, not larger than dorsals. Proximal caudal scales anterior to first autotomy segment distinctly heterogeneous, sotter and somewhat larger than preceding dorsals. Distal caudal scales enlarged, squarish, diagonally keeled above and below. Upper limb scales smooth, imbricate; ventral limb scales mostly smaller and imbricate, granular close to axilla and in posterior region of thigh. Femoral patch of enlarged scales evident. Supracarpals, supratarsals and supradigitals smooth. Infradigitals lamellae distinctly tricarinate. Scales at midbody $75 ; 29$ lamellae under the fourth toe; 9 preanal pores.

Snout-vent length $92 \mathrm{~mm}$; tail $111 \mathrm{~mm}$; foreleg $31 \mathrm{~mm}$; hind leg $50 \mathrm{~mm}$; distance from axilla to groin $41 \mathrm{~mm}$.

Head black above and on sides, with scattered white spots forming three transverse bands from subocular to supralabials. Interparietal white. Dorsum and upper surface of limbs brillant yellow or greenish with irregular dark brown reticulations. Ventral surface yellow; anterior gular region white, black-spotted. Strongly melanic ventrally, the black color extending on throat, belly, thighs and cloacal region; no distinct black gular collar evident. Tail yellowish with irregular brown marks.

Variation. A total of 12 adult males and 9 adult females have been examined for gonadal structure and sex maturity. The minimum, average and maximum s- $v$ length in both sexes are: 75.0 (84.2 \pm 3.5$) 94.0$ in males, $65.0(75.0 \pm 5.1) 83.0$ in females. No significant sex differences in size are found. The range of midbody scales is $66-77$. The color pattern is variable on the borders of regions where xanthoviridis occurs. West of Gran Laguna Salada and Rio Chico, a tributary of Rio 


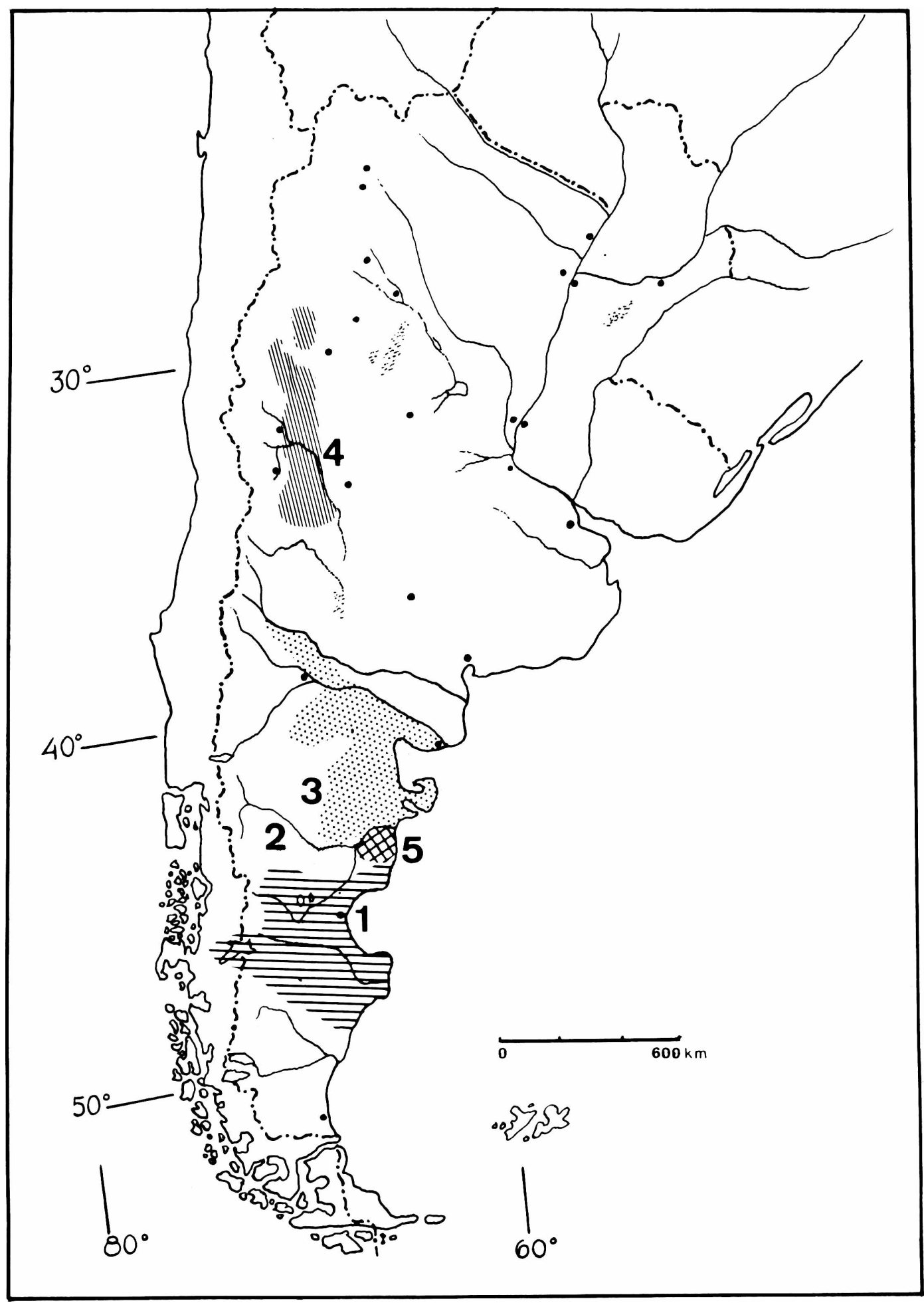

FIGURE 3. Distribution of geographical races of the Argentine Lolaemus fitzingeri complex:1-L. fitzingeri fitzingeri; $2-L$. fitzingeri canqueli; 3-L. fitzingeri melanops; $4-$ L. fitzingeri cuyanus; $5-L$. fitzingeri xanthoviridis. 
Chubut, transition populations to the color pattern of fitzingeri canqueli have been observed. The females of xanthoviridis show a pattern similar to, but less vivid than, the males, having ground color yellowish-olive, ventrally whitish. No vivid cephalic spots are present. The throat is similar to that of males, but ventral melanism is attenuated.

Range. This form occurs only on the xeric coast between northern Rio Chubut and southern Bahia Santa Cruz, entering inland to the Gran Laguna Salada basin through the flat embossment of Meseta de Montemayor. It contacts $L$. fitzingeri melanops, $L$. fitzingeri canqueli and the nominate form that extends from Santa Cruz to about $44^{\circ} \mathrm{S}$ near Cabo Raso, on the Atlantic shore.

Etymology. The subspecific name xanthoviridis is greek-latin for yellow green and refers to the brilliant color of this form.

\section{REMARKS}

The wide range of the species is shown in Fig. 3. Although contiguous subspecies may intergrade through peripheral areas, no clines in size variation, size of dorsal and ventral scales, body-limb ratio or color pattern can be reported for the $L$. fitzingeri group. Ecological features of $L$. fitzingeri cuyanus emphasize its specialization as a psammophilous lizard. Such a predominant adaptive trend is not so evident in L. fitzingeri melanops and $L$. fitzingeri canqueli, often living in open brush and ravines. L. fitzingeri xanthoviridis and L. fitzingeri fitzingeri are also found on clay and pebbly soil in the low mesetas bordering Atlantic shores, scattered with spiny bushes of Schinus, Berberis and Menodora robusta. Probably the forms contact south of the Dos Pozos depression, near Punta Clara promontory $\left(44^{\circ} \mathrm{S}\right)$.

It is remarkable that close serological relationships, at a true populational level, are pointed out by crossed precipitin tests between distinct geographical races such as $L$. fitzingeri melanops and $L$. fitzingeri cuyanus (Cei and Scolaro, 1977b). That may suggest a probable late differentiation of the latter from high Patagonia populations, having in mind the wide extent of semiarid and sandy continental areas north of Rio Colorado during the climatic phases of Pleistocene (Groeber 1936; Solbrig, 1976). Similar effects of this paleoclimatic factor seem to have played a role in the present geographical distribution of the psammophilous Liolaemus multimaculatus group (Cei, 1979).

\section{ACKNOWLEDGMENTS}

We thank B. Lanza and the Museo Zoologico of Florence, Italy, for interest and financial support during a part of this research. We are also grateful to J. Lescure of the Museum National d'Histoire Naturelle, Paris, for his suggestions and criticism during the preliminary discussion of the syntypes in his care.

\section{LITERATURE CITED}

Boulenger, G. A. 1885. Catalogue of the lizards in the British Museum (Nat. Hist.) London. V 1:436 pp.

Cei, J. M. 1973. Herpetologia Patagónica VI. Los Liolaemus del grupo fitzingeri en Santa Cruz y Chubut. Physis 32 (85c):447-458

1975. Liolaemus melanops Burmeister and the subspecific status of the Liolaemus fitzingeri group (Sauria, Iguanidae). J. Herpetol. 9:217-222.

. 1979. A reassessment of the genus Ctenoblepharis (Reptilia, Sauria, Iguanidae) with a description of a new subspecies of Liolaemus multimaculatus from western Argentina. J. Herpetol. 13:297-302.

- and J. A. Scolaro. 1977a. Herpetologia Patagonica XIII. La identidad de Liolaemus goetschi y de la forma melanops del grupo Liolaemus fitzingeri, en Rio Negro y Chubut. Physis 36 (92c):225-226.

$977 \mathrm{~b}$. Herpetologia Patagónica XIV. Nuevos datos inmunológicos sobre iguanidos argentinos del grupo Liolaemus fitzingeri. Physis 37 (93c):223-226.

Donoso Barros, R. 1966. Reptiles de Chile. Ed. Univ. Chile, Santiago:458 pp.

Dumeril, A. M. C. and G. Bibron. 1841. Erpetologie Generale, Paris 8:792 pp. 
Groeber, P. 1936. Oscilaciones de clima en la Argentina desde el Plioceno. Rev. Centro. Est. Doct. Ci. Nat. Buenos Aires $1: 71-84$.

Koslowsky. J. 1895. Batracios y reptiles de Rioja y Catamarca, recogidos durante los meses de Febrero a Mayo de 1895. Rev. Mus. La Plata 6:333-344.

Muller, L. and W. Hellmich. 1938. Liolaemus Arten aus dem Westlichen Argentinien. I-Liolaemus darwini und Liolaemus goetschi. Zool. Anz. 123:130-142.

Peters, J. A. and R. Donoso Barros. 1970. Catalogue of the neotropical Squamata. II-Lizards and amphisbaenians. US Nat. Mus. Bull. 297:293 pp.

Scolaro, J. A. and J. M. Cei. 1977. Herpetologia Patagónica XII. Los iguanidos del grupo Liolaemus fitzingeri en Chubut: datos serologicos y posición taxonomica. Physis $36(92 \mathrm{c}): 219-223$.

Solbrig, O. T. 1976. The origin and floristic affinities of the South American temperate desert and semidesert regions. In: D. W. Goodall, (ed.) Evolution of Desert Biota. pp. 6-49. Univ. Texas Press.

Accepted 26 Sept 1979

Copyright 1980 Society for the Study of Amphibians and Reptiles 